symposium followed the lines of the "old labor history," its creative work on mass insurgency and socialism demonstrates that those lines are by no means all played out.

\author{
Alan Dawley \\ Langhorne, Pa.
}

\title{
AMERICAN ITALIAN HISTORICAL ASSOCIATION: ELEVENTH ANNUAL CONFERENCE
}

"The Italian American Working Class" was the theme of the Eleventh Annual Conference of the American Italian Historical Association held at John Carroll University in Cleveland on October 27 and 28, 1978. The conference brought together academics from several disciplines, students, and members of Cleveland's Italian American community.

Since its beginnings in 1966, the American Italian Historical Association has sponsored yearly conferences on some aspect of Italian American life. Previous conference topics have included "The Italian American Novel," "The Interaction of Italians and Jews in America," "The Religious Experience of Italian Americans," "Italian American Radicalism," and "The Italian Immigrant Woman in North America." The proceedings of most AIH conferences have been published and the proceedings of the 1978 conference will be available in 1979.

Papers presented at the 1978 conference covered a wide range of aspects of working-class life among Italian Americans. Most papers examined workers and their lives during the years of mass emigration from Italy. However, papers on the experiences of a group of Italian American Vietnam veterans (Frank Milano), on Italian American political consciousness (Charles La Cerra), and on the folk roots of modern Italian feminism (Lucia Chiavola Birnbaum) brought the conference audience into the contemporary world.

In keeping with a recent trend in ethnic history, researchers did not limit their investigations to the experiences of immigrants in the urban Northeast, where the majority of Italian Americans lived. In a session on "Italians in the Mines," Phillip Notarianni summarized immigrant participation in a UMW strike in southern Colorado and Utah. Separate sessions examined Italians in Chicago and in Rhode Island through film and slides, while a panel discussed the Italians of Cleveland.

Papers in a number of sessions focused on Italian immigrants' role in organized labor activities. A major session on labor, chaired by Luciano Iorizzo, President of the AlH, included papers by Rudolph Vecoli: "Anthony Capraro and the Lawrence Strike of 1919," by Robert Harney: "The Padrone 
System and Sojourners in the Canadian North, 1885-1910," and by George Pozzetta: "Italians and the Tampa General Strike of 1910." In a session on "Women and the Work Experience," Jean Scarpaci presented a paper on "Angela Bambace: Union Activist and Labor Leader," while Colomba Furio examined the relationship between family roles and union activism in "Italian Immigrant Women and Unionization of New York's Garment Industry." A third session included "Italian American Radicals and the Rhode Island Labor Movement 1905-1930" by Paul Buhle.

A second theme of conference papers was working class residential areas and neighborhoods. In a session "Housing and Occupational Patterns," Gary Mormino pointed to the importance of homeownership in the emergence of a stable ethnic enclave. A second session on "Working Class Neighborhood" included papers by Phyllis Martinelli on San Francisco, by Rose Ann Rabiola on Chicago's Bridgeport area and by William Simons on Bloomfield.

Since the majority of Italian immigrants were workers for many years after their arrival in this country, papers such as those given at this conference fall into the category of the history of working class experiences. Nevertheless, the papers pointed to noticeable diversity in the experiences of Italian immigrant workers in different parts of the country and at different periods of time. The conference might have benefited from a general overview of the differentiation and interaction of class-determined and ethnic-determined experiences in the creation of working class identity and behavior.

\author{
Donna R. Gabaccia \\ University of Michigan
}

\title{
NETWORK ON WORKERS AND INDUSTRIALIZATION MEETING
}

Members of the Network on Workers and Industrialization gathered for their annual meeting at the Social Science History Association Convention in Columbus, Ohio, October 1978. (It will be recalled that the meeting was held in Columbus after the Association's Executive Board decided not to schedule a Chicago meeting because of the ERA boycott, a position the Network had urged it to adopt.) Network Convenor (Chair) David Montgomery of the University of Pittsburgh, who was instrumental in establishing the vitality of the group, resigned his post because of his new editorship of ILWCH. Charles Stephenson (SUNY Brockport) was then elected to succeed Montgomery. All members of the Steering Committee, including Montgomery and Stephenson, Michael Hanagan (Vanderbilt University), Elizabeth Pleck (University of 